\title{
Development of Dynamic Computer Aided Instruction for the Least Learned Topics in National Certificate II Animation
}

\author{
Mary Ann A. Aguilar ${ }^{1}$, Roberto R. Coloma ${ }^{2}$, Day Bert R. Mariñas ${ }^{3}$ Frederick Patacsil $^{4}$ \\ ${ }^{1}$ Lananpin National High School, Philippines, maryann.aguilar002@ deped.gov.ph \\ ${ }^{2}$ Lananpin National High School, Philippines, roberto.coloma002@ deped.gov.ph \\ ${ }^{3}$ Catablan Integrated School, Philippines, daybert.marinas@ deped.gov.ph \\ ${ }^{3}$ College of Computing, Pangasinan State University, Philippines, frederick_patacsil@yahoo.co.uk
}

\begin{abstract}
The K-12 program of the Department of Education ensures that a grade 12 students are equipped with life-long learning skills after graduation. Thus, they undergo an assessment test in Technical Vocational Livelihood Development Authority (TESDA) to enforce quality of acquired skills. Animation NC II is one of the specialization courses offered by schools. Urdaneta City National High School had encountered a low passing rate in the said course. The researchers developed a Computer Aided Instructions that would help students learn the course. The descriptive and developmental research design was used to develop and validate the CAI. The respondents were comprised of 15 animation students in the school year 2018-2019 and the 3 Animation teachers. A Likert-type perception instrument was used to determine the least leaned topics in Animation NC II and perceived delivery mode of lessons. The following conclusions can be drawn based on results from the study. First the least learned topics found in Animation in NC II were important competencies that a student should have to pass the National Assessment for NC II. Consequently, this was due to the students' low passing rate. Second, adequate delivery of learning should be established. This would assist them in improving their abilities. Learners and the teachers had very positive evaluations about some aspects of the CAI program: the content of the program, design, and learner's interaction with the CAI program.
\end{abstract}

Key words: Animation NC II, Computer Aided Instruction, Descriptive and Developmental research design, Philippines

\section{INTRODUCTION}

Computer Aided Instruction (CAI) has been regarded as a continuous approach to learning the skills and knowledge of students who use a computer as a key component to support instruction through activities, practices and drills, simulation, interaction, including the presentation of content, evaluation of progress and guidance. CAI is a component of technology-aided teaching which is different from online, Internet, or other network learning, in that CAI means that the program is local to the machine, not accessible through the Internet. Given its tremendous use in the education field, CAI can be a big help to teachers, students, and even parents to get through these troubled educational times because of the COVID-19 crisis. With regards to teaching and learning, students of all ages cannot attend school, and educators and parents must help them learn at home. This situation has transformed learning situation in some countries.

John Dewey an American philosopher, education reformist, and psychologist once said, "If we teach today as we taught yesterday, we rob our children of tomorrow. By doing CAI Instruction we can help students who are having difficulty and do not fully understand their lessons. Studies have shown that CAI, an up-to - date teaching tool, can be an important supplementary aid used to enhance student achievement.

In the Philippines, around 27 million learners, 1 million teachers and staff and even the families of learners, were affected by the Covid-19 crisis [1]. Despite of facing such situation, Department of Education (DepEd) proposed a learning continuity plan, instead of physical classes, the DepEd will implement distance or remote learning and called it "the new normal" wherein aside from the traditional face-to-face classroom interaction, new learning environment will be introduced to students and it will be soon the normal setting. In particular, students are now taking more responsibility in their own schooling and learning process and, in such a scenario, the student's progress in learning the subject 's skills on their own can be challenging, particularly with specialization subjects in high school, such as Animation NCII, there have been topics that need professional assistance from teachers. Therefore, researchers come up with developing a CAI as one remediation and intervention. Eventually, by use of CAI material to improve any teaching modalities was an innovative strategy. However, through the pressures at all education levels, a need for time efficient, appropriate teaching and learning approaches that 
maintained the quality education was perpetuated. CAI was viewed as a viable alternative to such problems.

The goal of the DepEd senior high school track is to train students with knowledge and skills to help them properly prepare for their chosen path, whether it be higher education, jobs, or entrepreneurship. The Technical Education and Skills Development Authority (TESDA) plays a critical role in reviewing and awarding the National Certificate (NC) for Technical Vocational and Livelihood Courses to expand the opportunities for students to work after graduation. Students who want to enroll in technical-vocational studies will undergo an examination and will receive either a National Certificate I (NCI) or a National Certificate II (NCII) qualification after passing.

Urdaneta National High School (UCNHS) is one of the biggest schools in Pangasinan and has the largest number of enrolled TVL senior high school students in Urdaneta City with a total of 384 in the School Year 2018-2019. Animation strand attributed $27.6 \%$ or 106 to that number and this is according to the school's enrolment registration record. In this note, passing percentage of Animation NC II in this school year accounts for $76.42 \%$ but the rest of the strands got $100 \%$ passing rate. Therefore, researchers' objective is to find out what topics in Animation, students had difficulty that might attributed to its passing percentages rate and to develop a computer aided instruction to supplement learning that can help the students achieve success in this course.

\subsection{Statement of the Problem}

The study aims to develop and validate a Computer Aided Instruction for the Least Learned Topics in Animation NC Specifically, this study will answer the following query.

1. What topics are the least learned topics in Animation $\mathrm{NC}$ II as perceived by the teachers and students?

2. What are the best ways to present/deliver least learned topics in Animation NC II as perceived by the teachers and students?

3. How to develop the proposed Computer Aided Instruction to aid students in learning the least learned topics in Animation NC II?

4. What is the level of acceptability and validity of the proposed Computer Aided Instruction for the least learned topics in Animation NC II in terms of:

I. Content Validity and Acceptability

a.) content accuracy and consistency

b.) flexibility

c.) Efficiency

II. Technical Quality Acceptability

a.) Screen Design

b.) Learner control and intractability

c.) Color

\section{REVIEW OF RELATED STUDIES}

This chapter contains related studies that are significant to the conceptualization of the developed CAI and served as bases and references for the developed system.
For the past decades, computer has seen a wide range of implementations in almost all human endeavors. It has also found its way into the school, universities and colleges, and educators are now looking at it as a perfect alternative to bring interactive lessons and address some pedagogical problems. One common technology used for education reasons is the CAI. Related studies show that CAI may be used to augment the teaching styles during classroom instructions. It may also be used as an alternative methodology to change the atmosphere in the classroom and discovered that it will further enhance the performance of students [2] [3].

\subsection{Computer Aided Instruction}

A study conducted by Leticia V. Marquez (2017) that the use of CAI for students with poor learning outcomes or with a diverse student population was suggested and that CAI should be used in the most effective and efficient way to increase learning outcomes. In addition to that the study revealed that CAI in college statistics was viewed as instructional media to help reinforce the teaching and learning process of students and faculty in statistics. It may also serve as motivational device to help students upgrade themselves with modern trends. The respondents find that the material is suited to the needs of the students, lessons are adequate to attain the objectives and lessons are suited to the level of appropriateness of the students. It is appropriate for the target users in terms of objective, content, technical quality, and instructional quality.

\subsection{CAI Relevance to Academic Performance}

According to the study of Suleman [4], computer-assisted instruction has a noticeable positive impact on the academic performance and retention of students in physics. Based on the results, it was recommended that science teachers could use computer-assisted teaching methods to encourage and improve the academic performance of students in physics at secondary school.

In addition to that, Nicolas [5] developed "Computer Aided Instructional Materials in Teaching Cookery in Grade 10". The result her study showed that "computer aided instruction enhances the learning abilities of the students and her study focus on the significant effect of computer aided instructional materials in teaching cookery in grade 10 in the level of performance of the students. The control group and the experimental group were both given a pretest, then exposed to different teaching methods. The experimental group was exposed to computer aided instructional materials while the control group was taught using the traditional approach. Both groups were given a post-test. The result showed that the Percentage score of the experimental group before the study was $34 \%$ and goes up to $97 \%$. It showed that there is a significant effect of Computer aided instructional materials in the performance level of the students."

\subsection{Methodology in Developing CAI}

ADDIE model is one of the most common models used in the instructional design field a guide to producing an effective 
design. This model is an approach that helps instructional designers, any content's developer, or even teachers to create an efficient, effective teaching design by applying the processes of the ADDIE model on any instructional product [6]. Gambari \& Yusuf [7] developed a "Computer Instructional Package on Physics for Secondary Schools in Nigeria" which proved the efficacy of CAI for improving students' performance in all disciplines, developing one for Nigerian physics students is inevitable. The package was developed in accordance ADDIE model. The validation was done in four stages: content validation (physics teachers); expert's validation (computer programmers and educational technology specialists); individualized validation (one-on-one validation by students) and cooperative validation (group validation by students). At the completion of the package, development and validation was found to produce a very good performance when used for physics instruction. Similarly, Widyastuti, Eri and Susiana [8] developed learning material for actuarial mathematics using the ADDIE model. The process of designing and development of the material teachings has followed the five steps in ADDIE model. The result of the content expert's validation was falling into agreement category, that of the instructional design expert's validation was agreement, that of the instructional media expert was agreement. In general, students and experts state that the module is qualified and easy to be understood. These reviews were considered in conducting this study. The researcher came up with the development of CAI to aid the learning of students in Animation NC II. The above studies showed that CAI can be used to improve learning outcomes of students and proven to be helpful. Furthermore, there was a significant increase in the level of performance of students when [5] used CAI in teaching TVL Cookery subject. With that the researchers, choose CAI as an intervention tool to deliver the lessons and its platform fits the situation today wherein there is no face-to-face interaction with the students and DepEd encourage the use of self - learning modules. In the instructional development perspective, the study of [8] [9] developed CAI in accordance with the ADDIE model. The researchers also decided to use this model in organizing and delivering the content of the developed CAI.

\subsection{Conceptual Framework}

In this study aimed to develop and validate a Computer Aided Instruction for least learned topics in Animation NC II, the researchers derived this study based on different concepts such as Curriculum Guide and Training Regulations, Assisted learning/Instruction, Self-paced learning, and Multimedia approach to learning. Computer Aided Instruction (CAI). it is referred to as the immersive use of computers. It can also be defined as a diverse and increasingly expanding range of computer technologies that support the teaching and learning process. The computer offers, receives, analyzes, and responds on an individual basis from each student. It's a way of individualized, programmed learning where smart students learn faster, and ordinary students learn at their own speed [3].

E-Learning. E-Learning is learning by using electronic tools to navigate instructional curricula beyond the conventional classroom. In most cases, this applies to a course program or level delivered exclusively online.

\subsection{Project Paradigm}

The project paradigm illustrates the conceptual framework of the study on how to come up with the output on Computer Aided Instruction for least learned topics in Animation NC II. The project paradigm includes the input, the process, and the output. The input is based on the (1) Identified least learned competencies/topics in Animation NC II perceived by teachers and students (2) Identified learning approach to deliver the least learned topics in Animation NC II. (3) Identified development requirements. (4) Validation in terms of i. content validity and acceptability; ii. Technical quality acceptability

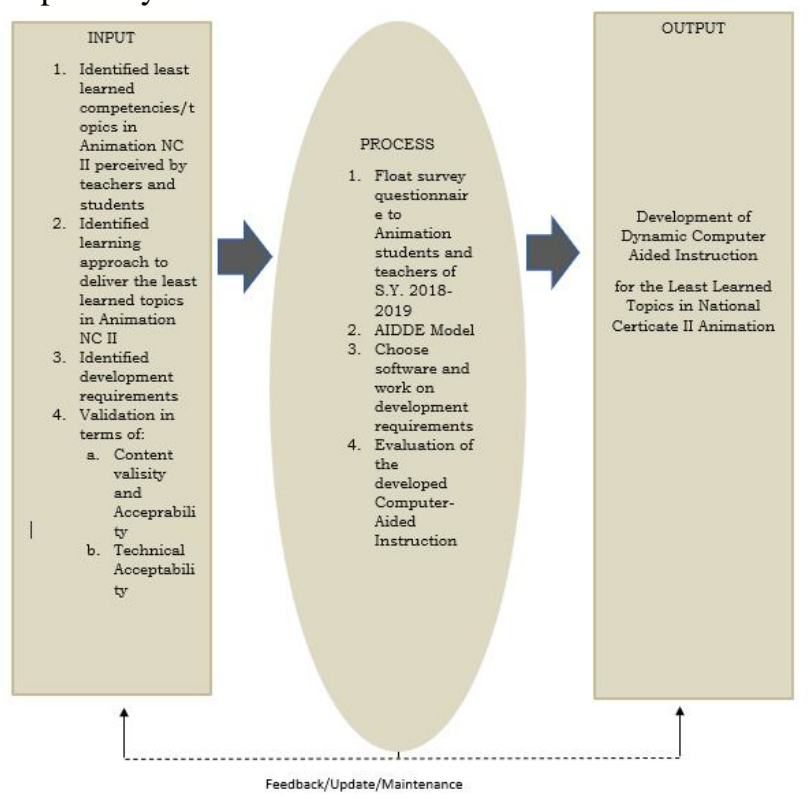

Figure 1: Research paradigm of the study

\section{METHODOLOGY}

This chapter presents the methods, designs and procedures that the researchers used in gathering data that are significant in the development of the CAI.

\subsection{Research Design}

In this study, a descriptive and developmental research design was used to develop and evaluate the computer-assisted instruction on least learned topics in Animation NC II.

3.1.1 Descriptive study is a form of research that accurately and systematically describes the population, circumstance or actions studied. It focuses on answering questions about how, when, where and where the situation is. 
The researchers used survey questionnaire as its method to collect information about the least learned topics in Animation NC II and ways to deliver or present the topics using CAI. This is based on the student's and teacher's perceptions. Respondents answered the survey questions through google forms.

3.1.2 Developmental research has been regarded as a systematic study of the design, development and evaluation of educational programs, procedures and products that must meet internal consistency and efficiency criteria. Situations in which the product development process is analyzed and described, and the final product is assessed, are the most common types of developmental research. A second type of development research focuses more on the impact of the product on the learner or the organization. A third type of study is aimed at a general analysis of the processes of design development or evaluation as a whole or as components [9]. Researchers came up with the development and validation of CAI and used developmental type of research as a guide in conducting this study.

\subsection{Research Instrument}

The instrument used was a survey questionnaire to collect essential data for this study. It was used to identify the perceived least learned topics in Animation NC II. The survey is divided into two parts: perceived least learned topics and the perceived mode of lessons delivery.

The first survey questionnaire is the list of topics in the curriculum were derived from the Curriculum Guide of Animation NC II of the DepEd and the Training Regulations of Animation NC II from TESDA. To ensure the validity of the instrument, it was checked by the Animation teachers who were Animation NC II holders and are experts in this field.

The researchers asked the Animation teachers of Urdaneta National High School and to 15 randomly selected previous animation current enrolled student respondents to answer the survey. The researchers discussed first the purpose of the survey to the Animation teachers and send them out the link where they can access the survey questionnaire and asked them also to send the link to their previously students.

The second questionnaire was used to determine the validity and acceptability of the CAI's instructions and contents in terms of its: (a) Accuracy and Consistency; (b) flexibility; (c) efficiency and its technical acceptability in terms of: (a) Screen design; (b) Learner control and Interactivity; (c) color. The questionnaire's criteria were taken in the study of [10] and modified few aspects to suit on this study's intended requirements.

To ensure the validity of this instrument the researchers performed a pilot-testing to teachers and students who were not an intended respondent of this study to test the developed CAI and use the instrument to evaluate it. During the pilot-testing, the researchers observed some aspects to improve such as: simplification of questions; time allotted to take the test and the time takes the CAI loads and unload information.

\subsection{Computer Aided Instruction Development Process (Data Gathering Procedure)}

Researchers designed and developed the CAI using ADDIE instructional framework model. "ADDIE" stands for Analyze, Design, Develop, Implement, and Evaluate.

According to Kurt [11], this model shows an iterative instructional design process, where the results of the formative evaluation of each phase may lead the instructional designer back to any previous phase. The end product of one phase is the starting product of the next phase. This sequence requires implementation and evaluation of each phases which is good to achieve the study's predetermined goals and that is to develop and confirm the validity and acceptability of the developed CAI.

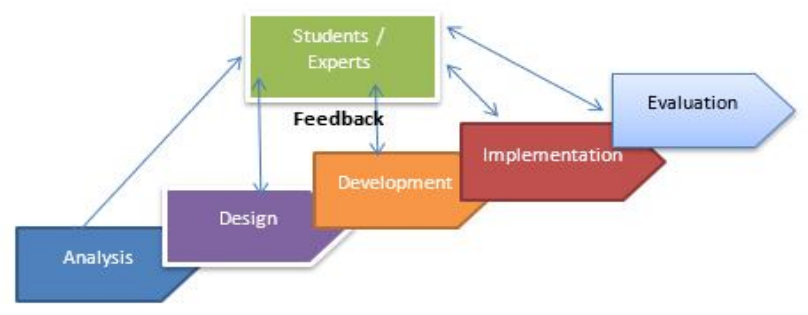

Figure 2: The Computer Aided Instruction Development Process

The objective of this study is to develop and validate a computer aided instruction for least learned topics in Animation NC II and followed the following process in developing:

During the Analysis phase, the Animation NC II DepEd Curriculum Guide and the TESDA Training Regulations were reviewed and topics to be included were defined. Survey was sent to teachers and students to determine the least learned topics, teaching and development preferences in animation.

In the Design phase, the researcher consulted teachers whose teaching animation, the topic of their expertise to decide certain essential design concepts and instructional arrangement based on the flow of their typical teaching plan framework. These concepts should be extended to the production of the instructional material of the CAI to improve quality.

In IT integration process and Development phase, the researchers used Kotobee application to design the least studied topics found in Animation NC II. Kotobee is an easy-to-use tool for producing immersive e-books and digital publishing material both online and offline while maintaining interactive features.

In the Implementation phase, During the implementation process, students and teachers of animation were asked to use and test the CAI material created.

In the Evaluation process, the student respondents, the teacher respondents, were asked to rate the CAI in terms of its material validity, acceptability, and usability.

Feedback of Students and teachers on evaluating the developed CAI were used as basis to improve the validity and acceptability of its content. 
Mary Ann A. Aguilar et al., International Journal of Advanced Trends in Computer Science and Engineering, 10(1), January - February 2021, 82 - 91

\subsection{Participants of the Study}

The respondents consist of fifteen (15) students of Urdaneta City National High School whose specialization is Animation during the school year 2017-2018, 2018-2019 and three (3) Animation specialization teachers. Students were randomly chosen though teacher respondents were purposively chosen. Students and teachers answered the survey questionnaire through google forms for data gathering analysis and able to determine what topics in animation were least learned. After that, students answered questions that assess CAI's acceptability. On the other hand, teachers gauged the developed CAI's validity.

\subsection{Statistical Analysis}

The following statistical methods and procedures were used to evaluate and interpret the collected data:

3.5.1 Frequency statistics counting the number of times that each item occurs. The researchers used this method to determine what topics in animation perceived to be difficult to learn by the students. The topics that had the highest number of frequency count in the survey will be the least learned topics/competencies.

3.5.2 Likert scale a rating scale utilized to measure attitudes or opinions. With this scale, respondents are asked to rate items on a level of agreement. This tool was used to measure the validity and acceptability of the developed CAI to a certain agreement. Researchers used 4-point Likert scale.

3.5.3 Average weighted mean is determined by assigning different weights to each of the individual values. If all the weights are equal, then the weighted mean is the same as the arithmetic mean. Some data points contribute more "weight" than others, instead of each data point contributing equally to the final mean.

To determine the validity and acceptability of the developed Computer Aided Instruction for least learned topics in Animation NC II, the weighted mean was employed to treat these problems. The formula for Average weighted Mean is:

Formula:

$$
A W M=T W P / N
$$

Where:

$$
\begin{aligned}
& \begin{array}{l}
A W M=\text { Average Weighted Mean } \\
W P= \\
\quad \text { Number of respondents per column multiplied by the } \\
\text { assigned numerical value }
\end{array} \\
& \begin{array}{ll}
T W P \quad=\text { The sum of the products in the column } \\
N \quad=\text { The number of respondents }
\end{array}
\end{aligned}
$$

The following scale was used, and the average weighted mean were further analyzed and interpreted.
3.5.4 Content Validity and Acceptability, and Technical Quality Acceptability

ValuesMean Scale; Descriptive Equivalent (DE); Descriptive Interpretation
$43.26-4.00 \quad$ Strongly Agree (SA) Valid
$32.51-3.25$ Agree (A) Valid
$21.76-2.5 \quad$ Disagree (D) Not Valid
$11.00-1.75$ Strongly Disagree (SD) Not Valid

Response ranging from 1.00 to 2.5 will be interpreted as not valid or not acceptable.

\section{RESULTS AND DISCUSSION}

This chapter overseen the presentation of data gathered by the researchers. This study aims to develop and validate a Computer Aided Instruction for the Least Learned Topics in Animation NC II. Researchers designed and developed the CAI using ADDIE instructional framework model. Data was analyzed and records were reviewed to address the questions presented in the problem statement. The analytical procedures were organized according to the set of questions.

4. 1. Least learned topics in Animation NC II. One of the problems encountered by UCNHS is the low passing percentage of Animation NC II assessment for the past two years and they had the least number of passers in the school year 2018-2019. In this note, researcher's objective is to find out what topics in Animation NC II these students had difficulty learning which resulted to a low passing rate.

A survey questionnaire was distributed to animation teachers

\begin{tabular}{|c|c|c|c|c|}
\hline \multirow[b]{2}{*}{$\begin{array}{l}\text { Animation NC II Topics and } \\
\text { Competencies }\end{array}$} & \multicolumn{2}{|c|}{ Teachers } & \multicolumn{2}{|c|}{ Students } \\
\hline & $\begin{array}{l}\text { Freq } \\
\text { coun } \\
t\end{array}$ & $\%$ & $\begin{array}{l}\text { Freq } \\
\text { count }\end{array}$ & $\%$ \\
\hline 1.PerformComputer Operations & 0 & 0 & 0 & 0 \\
\hline \multicolumn{5}{|c|}{ 2.Apply traditional drawing techniques for animation } \\
\hline $\begin{array}{l}\text { 2.1Identify traditional drawing } \\
\text { requirements for animation }\end{array}$ & 0 & 0 & 1 & $7 \%$ \\
\hline $\begin{array}{l}\text { 2.2.Apply hand } \\
\text { techniques }\end{array}$ & 0 & 0 & 7 & $47 \%$ \\
\hline $\begin{array}{l}\text { 2.6 Apply line art drawings } \\
\text { based on model sheet }\end{array}$ & 0 & & 8 & $53 \%$ \\
\hline \multicolumn{5}{|c|}{$\begin{array}{l}\text { 3. Produce Traditional cleaned-up key Drawings (Linetest software, } \\
\text { Appropriate position of drawing labels) }\end{array}$} \\
\hline $\begin{array}{l}\text { 3.1.Prepare Traditional Rough } \\
\text { Key Drawings }\end{array}$ & 1 & $33 \%$ & 6 & $40 \%$ \\
\hline $\begin{array}{l}\text { 3.2.Key drawing \& Breakdown } \\
\text { labels) Edit / Revise } \\
\text { cleaned-up Key Drawings }\end{array}$ & 1 & $33 \%$ & 8 & $53 \%$ \\
\hline 4. $\quad$ Produce traditional & & & & \\
\hline
\end{tabular}
and students and identified the least learned topics in Animation NC II and possible strategies for providing these lessons.

Table 1: Perceived least learned topics in Animation NC II by the teachers and Students 
Mary Ann A. Aguilar et al., International Journal of Advanced Trends in Computer Science and Engineering, 10(1), January - February 2021, 82 - 91

\begin{tabular}{|c|c|c|c|c|}
\hline in-between drawings & & & & \\
\hline 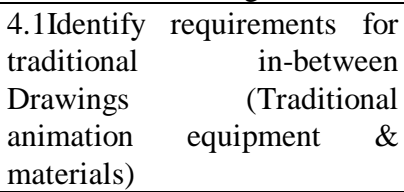 & 3 & $100 \%$ & 9 & $60 \%$ \\
\hline \begin{tabular}{lrr} 
4.2.Prepare & \multicolumn{2}{c}{ materials for } \\
traditional & 1 & In-between \\
drawings & & \\
\end{tabular} & 3 & $100 \%$ & 14 & $93 \%$ \\
\hline $\begin{array}{l}\text { 4.3.Produce traditional } \\
\text { in-between drawings }\end{array}$ & 3 & $100 \%$ & 15 & $\begin{array}{c}100 \\
\%\end{array}$ \\
\hline $\begin{array}{l}\text { 4.4.Edit / Revise in-between } \\
\text { drawings (revision calls) }\end{array}$ & 3 & $100 \%$ & 15 & $\begin{array}{c}100 \\
\%\end{array}$ \\
\hline
\end{tabular}

The Table 1 shows that least learned topics in Animation NC II perceived by the teachers are the topics under "Produce traditional in-between drawings". Further, the Table shows that the topic Produce traditional in-between drawing got the highest number of frequency count. This means that least learned topics in Animation NC II perceived by the student are the topics under "Produce traditional in-between drawings". These topics are the essential competencies that a student should possess to pass the Animation NC II assessment.

\subsection{Perceived mode of lesson delivery}

Table 2: Perceived Mode of lesson delivery using CAI by the animation teachers and students

\begin{tabular}{|c|c|c|c|c|}
\hline \multirow[b]{2}{*}{ Lesson Content } & \multicolumn{2}{|c|}{ Teachers } & \multicolumn{2}{|c|}{ Students } \\
\hline & $\begin{array}{l}\text { Freq } \\
\text { Count }\end{array}$ & $\%$ & $\begin{array}{l}\text { Freq } \\
\text { Count }\end{array}$ & $\%$ \\
\hline $\begin{array}{l}\text { 1.Text To present theories } \\
\text { and concepts }\end{array}$ & 1 & $33 \%$ & 5 & $33 \%$ \\
\hline $\begin{array}{l}\text { 2. Video Synchronize video } \\
\text { with content, and reinforce } \\
\text { /repeat the concepts being } \\
\text { presented }\end{array}$ & 3 & $\begin{array}{l}100 \\
\%\end{array}$ & 10 & $67 \%$ \\
\hline $\begin{array}{l}\text { 3.Audio Use audio when the } \\
\text { message is short and audio } \\
\text { rather than text for long passages }\end{array}$ & 3 & $\begin{array}{l}100 \\
\%\end{array}$ & 5 & $33 \%$ \\
\hline $\begin{array}{l}\text { 4.Animation for the explanation } \\
\text { of dynamic processes }\end{array}$ & 3 & $\begin{array}{l}100 \\
\%\end{array}$ & 11 & $73 \%$ \\
\hline $\begin{array}{l}\text { 5.Graphics Supplement } \\
\text { information with graphics } \\
\text { so it is better understood and } \\
\text { retained by the learner }\end{array}$ & 1 & 335 & 12 & $80 \%$ \\
\hline $\begin{array}{l}\text { 6.Interaction Use to supplement } \\
\text { information }\end{array}$ & 2 & $67 \%$ & 9 & 60 \\
\hline \multicolumn{5}{|l|}{ 7.Practice and Drills } \\
\hline $\begin{array}{l}\text { 7.1.Simulation Use for drawing } \\
\text { exercises }\end{array}$ & 3 & $\begin{array}{l}100 \\
\%\end{array}$ & 15 & $\begin{array}{l}100 \\
\%\end{array}$ \\
\hline $\begin{array}{l}\text { 7.2.Interaction Use to give short } \\
\text { instructions to processes }\end{array}$ & 3 & $\begin{array}{l}100 \\
\%\end{array}$ & 9 & $60 \%$ \\
\hline $\begin{array}{l}\text { 7.3.Problem Solving Use to } \\
\text { practice creativity and critical } \\
\text { thinking }\end{array}$ & 3 & $\begin{array}{l}100 \\
\%\end{array}$ & 15 & $\begin{array}{l}100 \\
\%\end{array}$ \\
\hline \multicolumn{5}{|l|}{ 8.Quizzes } \\
\hline 8.1.Games & 2 & $67 \%$ & 13 & $87 \%$ \\
\hline 8.2.Simulation & 3 & $\begin{array}{l}100 \\
\%\end{array}$ & 12 & $80 \%$ \\
\hline
\end{tabular}

\begin{tabular}{|l|l|l|l|l|}
\hline 8.3Text & 1 & $33 \%$ & 12 & $80 \%$ \\
\hline 8.4 Graphics & 1 & $33 \%$ & 8 & $73 \%$ \\
\hline 9.Feedback & 3 & $\begin{array}{l}100 \\
\%\end{array}$ & 7 & $47 \%$ \\
\hline $\begin{array}{l}\text { 9.1.Provide feedback immediately } \\
\text { following a response }\end{array}$ & 3 & $\begin{array}{l}100 \\
\%\end{array}$ & 13 & $87 \%$ \\
\hline $\begin{array}{l}\text { 9.2.Provide feedback to verify } \\
\text { correctness }\end{array}$ & 3 & $\begin{array}{l}100 \\
\%\end{array}$ & 9 & $60 \%$ \\
\hline 9.3Provide encouraging feedback & 3 &
\end{tabular}

Table 2 shows that the teachers wants an interactive and responsive Computer Aided Learning materials. Lesson content with audio, video and animation got the highest number of frequency count. Practice and drills were expected to have simulation, interaction and problem-solving these strategies got the highest number of frequency. Simulation format of quizzes got the highest number of counts. Feedback is necessary as it got the highest number of counts. In addition, Table 2 shows that students perceived way of delivering Animation lessons are: graphics, animation, and video; practice and drills, simulation and problem-solving got the highest frequency count (15); quizzes, simulation and text got 12 ; Feedback to verify correctness got 13 count.

\subsection{The Development of the CAI}

The researcher developed Computer Aided Instruction for the Least Learned Topics in Animation NC II using ADDIE's model as guide. We applied five steps instructional development model, including Analysis, Design, Development, Implementation, and Evaluation. In the analysis phase the researcher identifies the problem and objectives. For the design phase, we designed the learning objects. In the development phase, the dynamic computer aided instruction for the least learned topics in animation $\mathrm{NC}$ II was created using the Kotobee Author program. In the implementation phase, this addresses the execution of the instructions. Finally, in the evaluation phase measured the students learning using the developed CAI.

In developing CAI, the researcher identifies the problem and objectives. For the design phase, we designed the learning objects. In the development phase, the dynamic computer aided instruction for the least learned topics in animation NC II were created by Kotobee Author program. In the implementation phase, this addresses the execution of the instructions. Finally, in the evaluation phase measured the students learning using the developed CAI.

In developing CAI, we used Kotobee Author, this application fits the requirements and offers a wide variety of features.

These following are the screenshots plates of the developed CAI: 


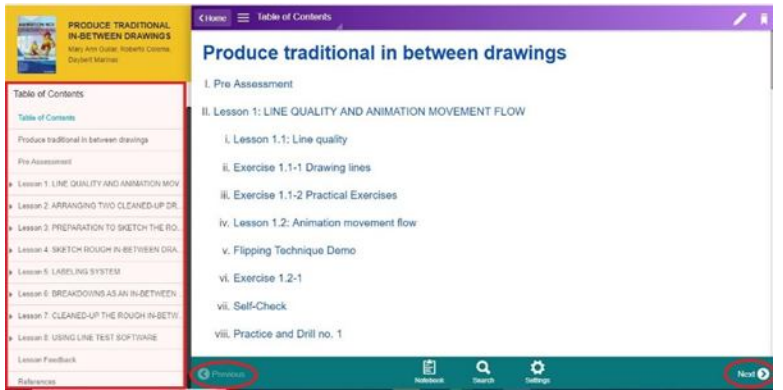

Figure 3: Table of Contents

In the left side of Figure 3 shows the list of links where we you find all the contents of the e-book also the lesson exercises. You can also access the previous and next lessons by clicking the button.

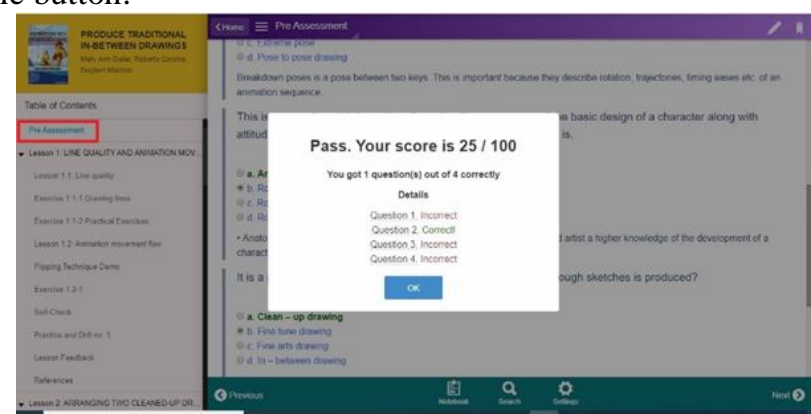

Fugure 4: Pre-assessment

Figure 4 shows the pre-assessment exercise, where you can answer all the given questions, then by clicking submit answer button your score will show if it is passes or fail, as you can see in the plate 2 , then click OK button.

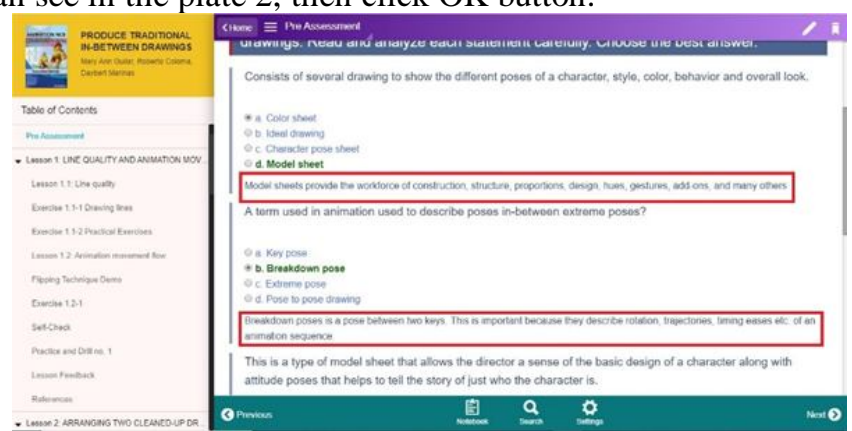

Figure 5: Pre-Assessment feedback

Figure 5 shows the feedback/explanation about each question

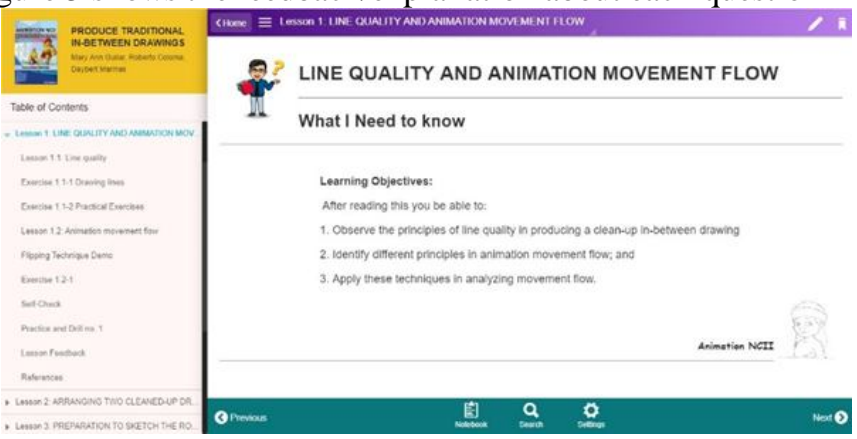

Figure 6: Lesson Objectives

Figure 6 shows the objectives of the lesson.

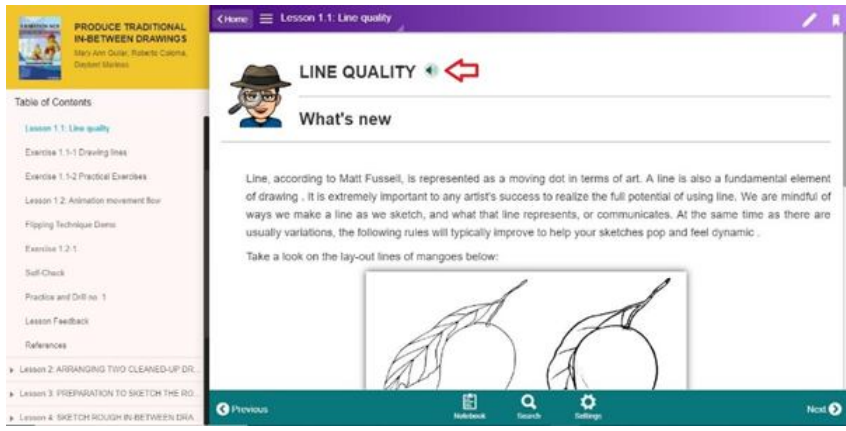

Figure 7: Lesson with audio

Figure 7 shows the lesson content, by clicking the audio icon you can turn reading material into audiobooks.

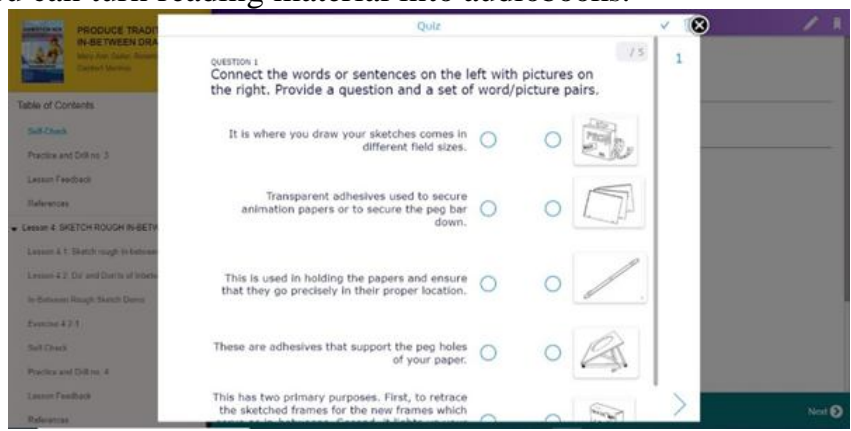

Figure 8: Interactive Quiz

Figure 8 shows the interactive matching type quiz using widgets. User can connect the words or sentences on the left with the pictures on the right side by drag and drop.

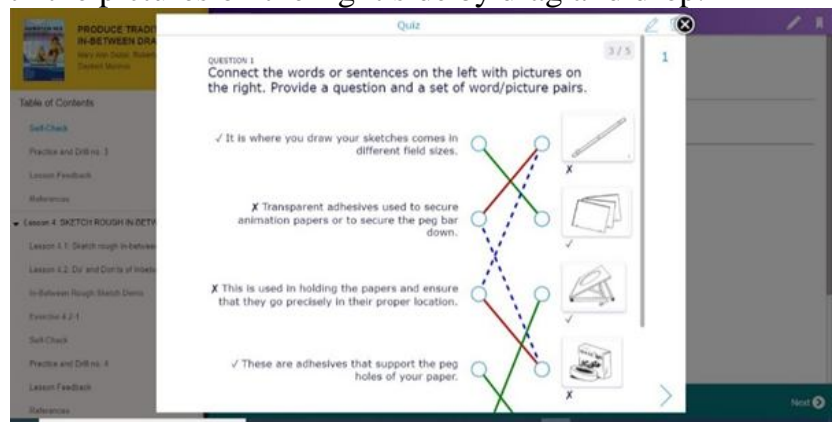

Figure 9: Sample Output Quiz

Figure 9 shows the sample accomplished interactive matching type quiz

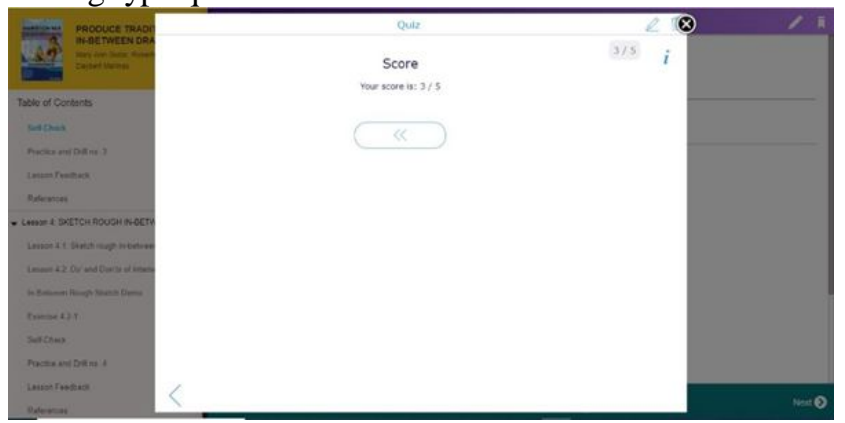

Figure 10 : Score

Figure 10 shows the user total score. 


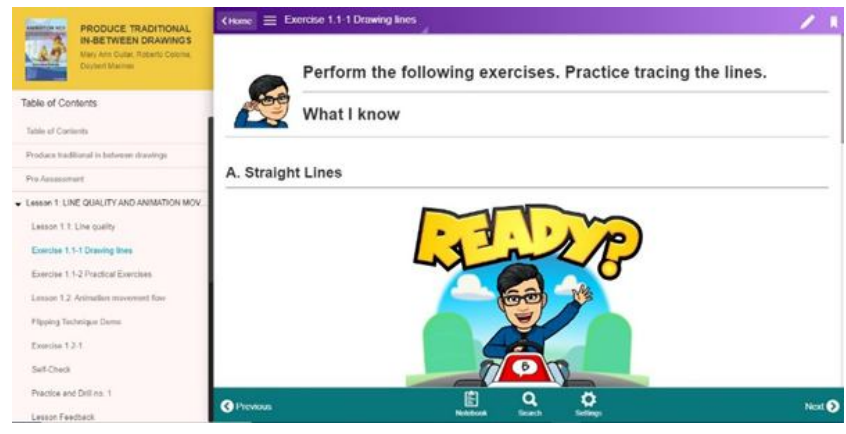

Figure 11: Simulation Practice and Drill

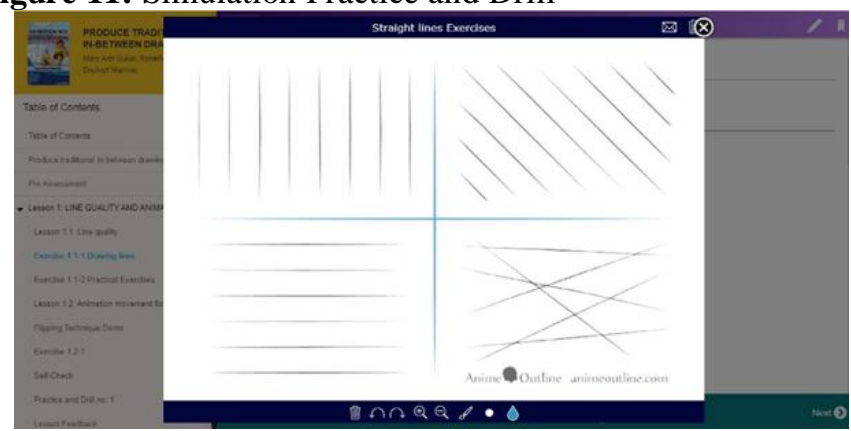

Figure 12: Tracing Activity

Figure 11 and 12 shows the screen interface where the user can perform or practice tracing lines.

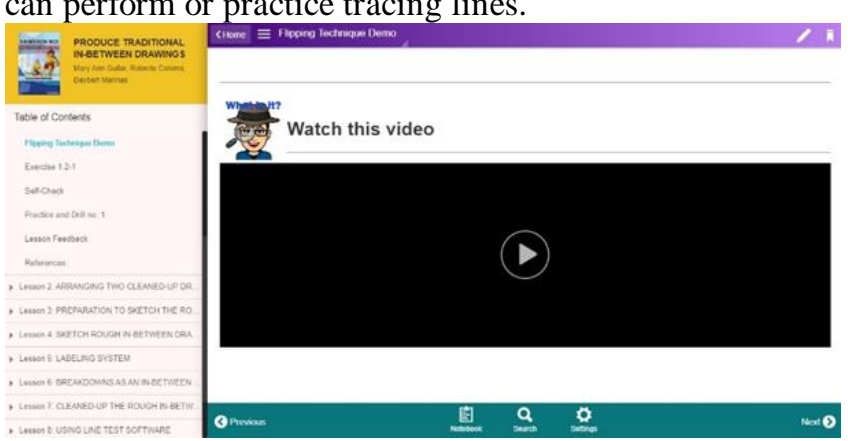

Figure 13: Video Tutorial

Figure 13 shows the video tutorial where the user can watch the lesson for them to guide and to understand the lesson better.

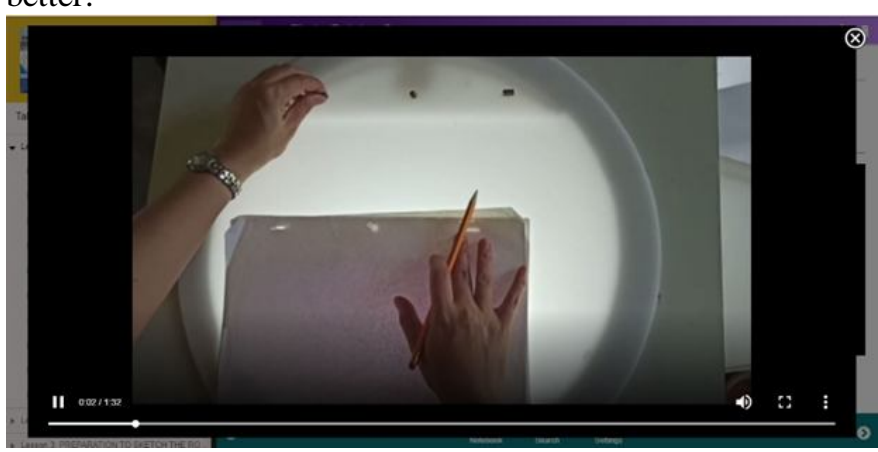

Figure 14: Video Tutorial

\subsection{Acceptability of the Computer Aided Instruction for the Least Learned topics in Animation NC II for the teachers}

Content Validity questionnaires for teachers were distributed as assessed along the following criteria: accuracy and consistency, flexibility, and efficiency.

Table 3 Developed CAI Content Validity and Acceptability

\begin{tabular}{|l|l|l|l|}
\hline Criteria & $\begin{array}{l}\text { Average } \\
\text { Weighted Mean }\end{array}$ & $\begin{array}{l}\text { Descriptive } \\
\text { Equivalent }\end{array}$ & $\begin{array}{l}\text { Descriptive } \\
\text { Interpretation }\end{array}$ \\
\hline $\begin{array}{l}\text { (a) Accuracy and } \\
\text { Consistency }\end{array}$ & 4.0 & Strongly Agree & Valid \\
\hline (b) Flexibility & 3.42 & Strongly Agree & Valid \\
\hline (c) Efficiency & 3.75 & Strongly Agree & Valid \\
\hline
\end{tabular}

Table 3 shows how the respondents rate the content validity and acceptability of the developed CAI is 3.72 which means the content validity and acceptability is valid. Technical quality questionnaires for teachers were distributed as assessed along the following usability: screen design, learner control and interactivity, and color.

Table 2 (b) Developed CAI Technical Acceptability

\begin{tabular}{|l|l|l|l|}
\hline Criteria & $\begin{array}{l}\text { Average } \\
\text { Weighted } \\
\text { Mean }\end{array}$ & $\begin{array}{l}\text { Descriptive } \\
\text { Equivalent }\end{array}$ & $\begin{array}{l}\text { Descriptive } \\
\text { Interpretation }\end{array}$ \\
\hline (a) Screen Design & 3.9 & Strongly Agree & Valid \\
\hline $\begin{array}{l}\text { (b) Learner control and } \\
\text { interactivity }\end{array}$ & 3.77 & Strongly Agree & Valid \\
\hline (c) Color & 4.0 & Strongly Agree & Valid \\
\hline
\end{tabular}

Table 2 (b) shows how the respondents rate the technical acceptability of the developed CAI is 3.89 which means it is valid.

\subsubsection{Acceptability of the Computer Aided Instruction for the Least Learned topics in Animation NC II for the students}

Acceptability questionnaires were distributed an assessed along the following dimensions: flexibility, efficiency, interactivity, screen design, learner control and interactivity, and color.

Table 4: Acceptability of CAI (Student)

\begin{tabular}{|l|l|l|l|}
\hline Criteria & Mean & $\begin{array}{l}\text { Descriptive } \\
\text { Equivalent }\end{array}$ & $\begin{array}{l}\text { Descriptive } \\
\text { Interpretation }\end{array}$ \\
\hline (a) Flexibility & 3.88 & Strongly Agree & Acceptable \\
\hline (b) Efficiency & 3.89 & Strongly Agree & Acceptable \\
\hline (c) Interactivity & 3.85 & Strongly Agree & Acceptable \\
\hline (d) Screen Design & 3.71 & Strongly Agree & Acceptable \\
\hline $\begin{array}{l}\text { (e) Learner Control and } \\
\text { Interactivity }\end{array}$ & 3.91 & Strongly Agree & Acceptable \\
\hline (f) Color & 4.0 & Strongly Agree & Acceptable \\
\hline
\end{tabular}


Mary Ann A. Aguilar et al., International Journal of Advanced Trends in Computer Science and Engineering, 10(1), January - February 2021, 82 - 91

Table 4 shows the result of the acceptability of the CAI is 3.87 which means it is acceptable.

\section{SUMMARY, CONCLUSION AND RECOMMENDATION}

This chapter presents the summary of the findings, conclusion and recommendations made by the researchers based on careful analysis, understanding and development of the developed study.

\subsection{Conclusion}

Based on findings from analysis, creation and validation, the following conclusions can be drawn as follows: First, the identified least learned topics in Animation in NC II were significant competencies a student should possess to pass the National Assessment for NC II. Thus, this attributed to the low passing rate of the students. Second, appropriate learning delivery should be identified. This would help them improve their skills in the said field.

The CAI was developed by using the ADDIE Model for teaching Animation covered the topic on producing traditional in-between Drawings. The Animation Module provides reference to the lesson entitled 'Produce traditional in-between drawing,' consisting of 17 pages of materials and questionnaire. With an appealing and readable text, narrative sound playback, sample graphics and animation, interactive games and assessment, the visual user interface (GUI) for the CAI catches the interest of the learners and teachers. The study showed that after finishing the test review, the learners and teachers are surprised and know the outcome instantaneously.

And finally, the learners and the teachers had very positive evaluations about some aspects of the CAI program: the content of the program, design, and learner's interaction with the CAI program.

\subsection{Recommendation}

The following are highly recommended to manage the efficiency of the developed system. The researchers highly recommend that the CAI system should also be tested and evaluated either by a larger group of learners and students from the private institution who also conducted a training for Animation NCII to use the program, or by IT/instructional experts. Researchers also recommend animation teacher should have a proper orientation on how to use the CAI, so that teachers can also supervise their learners. Continuous Program Development is recommended in the conduct of related studies as it has been seen to be sufficient for the development of the system. Researchers are recommending that the developed system should be implemented in the school or private institution offering the Animation course to innovate the learning experience of their learners. Further analysis needs to be done to enhance the developed system or to add innovative features and new trends content to the Computer Aided Instruction that will benefit the school.

\section{REFERENCES}

1. J. Obana. What will schools look like under the 'new normal' Retrieved Oct 20, 2020 from https://www.manilatimes.net/2020/05/13/business/colu mnists-business/what-will-schools-look-like-under-thenew-normal/724556/, May 2020.

2. Barlis Jr. J, Fajardo III. JD. Effectiveness of simulation and Computer Assisted Instruction (CAI) on the performance of students under regimental training on selected topics in physics II. International Journal of Applied Physics and Mathematics. 2013;3(1). Available:http://www.ijapm.org/papers/180-ST0008.pdf

3. Koledafe, O.S., Ogunlade, O.O. and Olafare, O.F., Design and Validation of Computer Assisted Instructional Package to Teach the Concept of Motion in SecondaryPhysics.

4. Suleman, Effects of Computer-Assisted Instruction (CAI) on Students' Academic Achievement in Physics at Secondary Level (2017).

5. S. Nicolas. Computer Aided Instructional Materials In Teaching Cookery In Grade 10: It's Effectiveness. Jisae: Journal of Indonesian Student Assessment and Evaluation, $\quad 5(2), \quad 112$. https://doi.org/10.21009/JISAE.052.01

6. ADDIE Model Nada Aldoobie University of Northern Colorado American International Journal of Contemporary Research Vol. 5, No. 6; December 2015

7. I. Gambari and M. Yusuf, .Development and Validation of Computer Instructional Package on Physics for Secondary Schools in Nigeria.Science Education Department, Federal University of Technology, Minna, Department of Educational Technology, University of Ilorin, NIGERIA. 1 gambari@ futminna.edu.ng, 2 moyusuf@unilorin.edu.ng Educational Research International Vol. 3(1) February 2014

8. Widyastuti, Eri \& Susiana,. Using the ADDIE model to develop learning material for actuarial mathematics. Journal of Physics: Conference Series. 1188. 012052. 10.1088/1742-6596/1188/1/012052.

9. R. Richey. Developmental Research: The Definition and Scope. https://eric.ed.gov/?id=ED373753, 1994

10. C. Diezmann \& J. Watters, A theoretical framework for multimedia resources: A case from science education. In AARE 2002 Conference Papers: (pp. 2-18). Australian Association for Research in Education.

11. S. Kurt. ADDIE Model: Instructional Design.

Retrieved Nov 06, 2020 from

https://educationaltechnology.net/the-addie-model-instr uctional-design/ADDIE Model: Instructional Design, (2018).

12. A. N. Che Pee1 , M. H. L. Abdullah1, M. H. Zakaria1, H. Asyrani1 , S. S. Rahim1 , L. C. Chuan1Role-Playing Computer Game to Improve Speech Ability of Down Syndrome Children, International Journal of Advanced Trends in Computer Science and Engineering, vol 9, 
Mary Ann A. Aguilar et al., International Journal of Advanced Trends in Computer Science and Engineering, 10(1), January - February 2021, 82 - 91

No.4., 2020.

https://doi.org/10.30534/ijatcse/2020/33792020

13. A. Chegenizadeh, M. Keramatikerman, \&H.Nikraz, Application of Innovative Technologies and Computer Aided Approach in a Resilient Teaching Practice for Engineering Students. International Journal of Advanced Trends in Computer Science and Engineering, vol 9, No.2.,2020.

https://doi.org/10.30534/ijatcse/2020/151922020 